\title{
Giant Cell and Spindle Cell Carcinoma
}

National Cancer Institute

\section{Source}

National Cancer Institute. Giant Cell and Spindle Cell Carcinoma. NCI Thesaurus. Code C65160.

A malignant epithelial neoplasm composed of giant, pleomorphic cells and spindle cells. 